\title{
Hak Waris Anak Angkat Menurut Fikih dan Kompilasi Hukum Islam (KHI)
}

\author{
Suaib lubis ${ }^{1}$, Khairani ${ }^{2}$
}

Sekolah Tinggi Agama Islam Jam'iyah Mahmudiyah, Tanjung Pura

Suaib.Lubis@staijm.ac.id

\begin{tabular}{l}
\hline INFO ARTIKEL \\
\hline Diterima \\
2 September 2019 \\
Direvisi \\
15 November 2019 \\
Disetujui \\
15 Desember 2019 \\
\hline
\end{tabular}

\section{Kata Kunci:}

Hak waris, Anak anngkat, warisan, fiqih, hukum

\section{ABSTRAK}

Kedudukan anak angkat hanya mempunyai perbedaan dengan anak kandung. Pengangkatan anak hanya sebagai perbuatan sosial saja. Hal ini biasanya dilakukan oleh orang kaya yang tidak atau belum mempunyai anak dan dia mengangkat anak karena bertujuan untuk ibadah. Anak merupakan nilai lebih bagi orang tua. Yang merupakan penerus bagi keluarga dan merupakan sebagai penyeimbang (balance) dalam kehidupan berumah tangga, anak adalah bukti bahwa ini hasil dari pernikahannya dan sebagai nilai yang berharga bagi keluarga. Masalah itupun terus berlanjut, hingga pada urusan tentang anak angkat. Mengambil anak angkat itu adalah suatu kebohongan dihadapan Allah, dan masyarakat, dan hanya merupakan kata-kata yang diucapkan berulang kali, tetapi tidak mungkin akan menimbulkan kasih sayang yang sesungguhnya, seperti yang timbul dikalangan ayah, ibu, dan kaum keluarga yang sesungguhnya.Jadi, mengambil anak angkat itu hanyalah mengungkapkan kata-kata yang tidak menunjukkan kebenaran, dan hanya mencampuradukkan keturunan yang kelak menyebabkan hilangnya kebenaran, dan runtuhnya ikatanikatan keluarga yang asli, dan mungkin akan mengakibatkan terkena kutukan Allah. Kedudukan anak angkat dalam KHI Pasal 171 Huruf h yang berbunyi: "Anak angkat adalah anak yang dalam hal pemeliharaan untuk hidupnya sehari-hari, biaya pendidikan dan sebagainya beralih tanggung jawabnya dari orang tua asal kepada orang tua angkatnya berdasar putusan pengadilan. Hingga saat ini, peraturan perundangundangan yang secara khusus mengatur mengenai pengangkatan anak belum ada, begitu pula hingga saat ini belum ada pengaturan yang pasti mengenai akibat hukum dari pelaksanaan pengangkatan anak. Dari ketentuan tersebut dapat disimpulkan bahwa dengan dilakukannya pengangkatan anak tidak memutus hubungan darah antara anak angkat dengan orang tua Kandungnya. Sedangkan pengangkatan anak (adopsi) menurut Staatsblad 1917 No. 129 menimbulkan akibat hukum bahwa anak yang diangkat oleh suami istri sebagai anak mereka, dianggap sebagai anak yang dilahirkan dari perkawinan suami istri tersebut.

\section{ABSTRACT}

Position adopted child only has differences with biological children. Adoption only as a social act alone. This is usually done 
Keywords:

Inheritance adopted inheritance, fiqh, law. by rich people who do not yet have children and she raised the child as it aims to worship. Son is a better value for parents. Which is the successor to the family and is a counterweight (balance) in the household life, the child is proof that this is the result of the marriage and as a precious value for families. The problem persists even then, until the affairs of the adopted child. Taking a foster child was a lie before God and society, and the only words uttered repeatedly, but it is not likely to pose a real affection, like that arise among fathers, mothers, and the real family. So, take a foster child was only expressing words that do not show the truth, and only confuses the descendants who would cause the loss of truth, and the collapse of the family ties of the original, and will probably result in the curse of God. Position adopted children in the Letter $h$ KHI Article 171, which reads: "The adopted son is the child in terms of maintenance for everyday life, educational expenses and so shift of responsibility from the parents of origin to the adoptive parents based on a court decision. Until now, legislation that specifically regulates the adoption of children not yet exist, nor did until now there is no definite pengatnran regarding the legal effect of the implementation of child adoption. Of these provisions can be concluded that the adoption did not break the blood relationship between the adopted child with his biological parents. While pengangkatrn child (adoption) according to the Government Gazette No. 1917129 legal consequences that children raised by married couple as their son, considered a child born of the marriage of husband and wife is.

\section{Pendahuluan}

Hak asasi anak merupakan bagian dari hak asasi manusia yang termuat dalam Undang-undang Dasar 1945 dan Konvensi Perserikatan Bangsa-Bangsa tentang hakhak anak. Dilihat dari sisi kehidupan berbangsa dan bernegara, anak adalah pewaris dan sekaligus potret masa depan bangsa dimasa datang, generasi penerus cita-cita bangsa sehingga setiap anak berhak atas kelangsungan hidup, tumbuh dan berkembang, berpartisipasi serta berhak atas perlindungan dari tindak kekerasan dan diskriminasi serta hak sipil dan kebebasan. Keinginan untuk memiliki anak adalah hal yang alami karena manusia memiliki akal sehat dan keinginan. Dengan akal pikiran manusia dapat menelaah serta mengkaji sesuatu agar terasa bermanfaat dan disisi lain keinginan tersebut mendorong manusia berusaha untuk memperoleh bahkan kadang menjurus kepada hal yang tidak mampu dan diluar kuasa manusia.

Undang-Undang Nomor 23 Tahun 2002 tentang Perlindungan Anak telah menegaskan bahwa pertanggungjawaban orang tua, keluarga, masyarakat, pemerintah dan negara merupakan rangkaian kegiatan yang dilaksanakan secara terus menerus demi terlindunginya hak-hak anak. Rangkaian kegiatan tersebut harus terus berkelanjutan dan terarah guna menjamin pertumbuhan dan perkembangan anak baik fisik, mental, spiritual maupun sosial. Tindakan ini dimaksudkan untuk mewujudkan kehidupan terbaik bagi anak yang diharapkan sebagai penerus bangsa yang potensial dan memiliki jiwa nasionalisme 
berdasarkan akhlak mulia dan nilai pancasila serta berkemauan keras menjaga kesatuan dan persatuan bangsa.Menurut ketentuan umum dalam kompilasi Hukum Islam Pasal 171 bahwa anak angkat adalah anak yang dalam hal pemeliharaan untuk hidupnya sehari-hari, biaya pendidikan dan sebagainya beralih tanggungjawabnya dari orang tua asal kepada orang tua angkatnya berdasarkan putusan pengadilan. Atas dasar pengertian tersebut jelaslah bahwa yang dilarang menurut Hukum Islam adalah pengangkatan anak sebagai anak kandung dalam segala hal. Dari sini terlihat adanya titik persilangan menurut hukum adat, yang menghilangkan atau memutuskan kedudukan anak angkat dengan orangtua kandungnya sendiri. Hal ini bersifat prinsip dalam lembaga Adopsi karena adanya ketentuan yang menghilangkan hak-hak ayah kandung dan dapat merombak ketentuan-ketentuan mengenai waris.

Berdasarkan uraian di atas, selayaknya apabila ada suatu cara untuk menjembatani masalah anak angkat, sehingga anak angkat dapat dipelihara dengan baik dan dapat terjamin masa depannya khususnya yang berkaitan dengan bagian waris anak angkat yang bersangkutan. Dengan demikian, adopsi yang dilarang menuntut ketentuan dalam hukum Islam adalah seperti dalam pengertian aslinya, yakni menurut versi Hukum barat yaitu mengangkat anak secara mutlak. Dalam hal ini adalah, memasukkan anak yang diketahuinya sebagai anak orang lain kedalam keluarganya yang tidak ada pertalian nasab kepada dirinya sebagai anak sendiri, yang menganggap anak itu merupakan anak kandung bagi dirinya dan keluarganya, seperti hak menerima warisan sepeninggalnya dan larangan kawin dengan keluarganya.

Upaya perlindungan terhadap anak perlu dilaksanakan sedini mungkin yaitu sejak dari janin dalam kandungan sampai anak berumur 18 (delapan belas) tahun. Hal ini bertitik tolak dari konsepsi perlindungan anak yang utuh, menyeluruh dan komprehensif. Undang-undang perlindungan anak juga harus meletakkan kewajiban memberikan perlindungan kepada anak berdasarkan asas-asas non diskriminatif, kepentingan yang terbaik bagi anak, hak untuk hidup, kelangsungan hidup dan perkembangan serta penghargaan terhadap pendapat anak. Di Indonesia, ada tiga sistem hukum yang berlaku dan mengatur permasalahan tentang pengangkatan anak. Ketiga sistem hukum itu adalah hukum Islam, hukum Adat dan hukum Barat. Agama Islam pada dasarnya tidak melarang praktek pengangkatan anak, sejauh tidak mempengaruhi dan tidak merubah hubungan nasab atau keturunan antara anak dengan orangtua kandungnya. Praktek pengangkatan anak akan dilarang ketika hal ini berakibat keluarnya anak angkat dari hubungan nasab atau keturunan antara anak dengan orangtua kandungnya sendiri dan masuk dalam hubungan nasab dengan orangtua angkatnya. Artinya anak angkat itu dianggap anak sah bagi orangtua angkatnya dan tidak dianggap lagi sebagai anak kandung bagi orangtua kandungya.

\section{Metodologi Penelitian}

Metodologi penelitian merupakan suatu cara yang ditempuh untuk melaksanakan penelitian. Penelitian ini menggunakan penelitian deskriptif. Penelitian deskripif dimaksudkan untuk memperoleh gambaran dengan cara menganalisis dan menafsirkan variabelvariabel yang diteliti. Sehingga nampaklah bahwa penelitian ini merupakan penelitiankualitatif dan bersifat deskriptif analitis. Metode yang digunakan untuk 
mengumpulkan data dalampenelitian ini adalah wawancara, observasi dan dokumentasi. Wawancaralebih fokus kepada sumber data primer yang ada yaitu orang yang berkaitan langsung dengan variabel penelitian. Untuk observasi dilakukandengan pengamatan langsung obyek maupun lokasi penelitian tersebut. Sedangkan dokumentasiyang terkumpul adalah proses penelitian yang dilakukan dari awal hingga akhir penelitian. Terlihatmodel analisis yang digunakan dalam penelitian ini adalah modelinteraktif (interactive model of analysis). Artinya, ketiga komponen dalam kegiatan penelitian berjalan bersama-sama, yakni data reduction (reduksi data), data display (penyajian data) dan conclusionsdrawing and verifying (penarikan kesimpulan dan verifikasi).

\section{Hasil Pembahasan}

Akibat Hukum Pengangkatan Anak

Dari ketentuan tersebut dapat disimpulkan bahwa dengan dilakukannya pengangkatan anak tidak memutus hubungan darah antara anak angkat dengan orang tua Kandungnya. Sedangkan pengangkatrn anak (adopsi) menurut Staatsblad 1917 No. 129 menimbulkan akibat hukum bahwa anak yang diangkat oleh suami istri sebagai anak mereka, dianggap sebagai anak yang dilahirkan dari perkawinan suami istri tersebut. Hubungan peidata antara orang tua dengan sanak keluarganya di satu pihak dengan anak tersebut di lain pihak menjadi putus, dengan perkecualian yang disebutkan dalam pasal 14 bila anak yang diadopsi itu mempunyai nama keluarga lain, karena hukum akan memperbolehkan nama keluarga dari ayah yang mengadopsi. Jika seorang suami mengadopsi anak setelah perkawinan bubar, maka anak tersebut dianggap lahir dari perkawinan pria tersebut yang telah bubar karena kematian istrinya.

Maksud ketentuan tersebut adalah anak itu harus dianggap telah dilahirkan dari suatu perkawinan fiktif, yaitu perkawinan antara ayahnya dengan seorang wanita yang sesungguhnya tidak ada, yang telah bubar karena istri telah meninggal dunia. Beberapa pakar berpendapat bahwa maksud dari ketentuan tersebut adalah bahwa adopsi oleh seorang suami setelah perkawinan bubar hanya mempunyai akibat hukum terhadap dia sendiri dan sanak keluarganya akan tetapi tidak terhadap bekas istri atau sanak keluarganya.

Lain halnya jika seorang janda mengadopsi anak setelah suaminya meninggal dunia, maka anak yang diadopsi hanya dapat dianggap sebagai ahli waris suami dari ibu angkatnya jika suami tidak memberikan ketentuan-ketentuan atau harta peninggalannya di dalam wasiatnya, maka hal ini berarti bahwa ketentuanketentuan dalam wasiat suami yang telah meninggal dunia tidak dapat diganggu gugat oleh anak angkat. Dengan demikian maka anak angkat tidak mempunyai legitime portie atas warisan suami dari ibu angkatnya. Selain itu, pasal 13 ayat (1) memerintahkan apabila seorang suami meninggal dunia dengan meninggalkan istri yang berwenang untuk mengadopsi, maka Balai Harta Peninggalan wajib mengambil tindakan-tindakan yang perlu dan mendesak untuk menyelamatkan dan mengurus harta peninggalannya yang akan jatuh pada anak yang diadopsi. Sedangkan hak-hak pihak ketiga yang dapat dipengaruhi oleh adopsi ini tetap ditangguhkan sampai dengan dilakukannya adopsi.

Tenggang waktu penangguhan itu selambat-lambatnya selama yang dimaksud oleh pasal 12 ayat (3) yaitu satu bulan. 
Adopsi yang telah dilakukan dalam jangka waktu enam bulan setelah meninggalnya suami atau janda dalam tenggang waktu itu telah meminta izin dari hakim seperti yang dimaksud dalam pasal 9. lalu dalam waktu satu bulan setelah izin atau kuasa itu diperoleh, ia baru menggunakan haknya. Apabila seorang janda yang melakukan adopsi, maka anak tersebut dianggap sebagai anak yang lahir dari janda tersebut dengan suaminya yang telah meninggal.

Dari pengertian tersebut anak angkat akan mendapatkan bagian warisan almarhum ayah angkatnya sejauh tidak ditentukan lain dalam surat wasiat almarhum semasa hidupnya dan sejauh adopsi tersebut dilakukan dalam jangka waktu 6 bulan terhitung mulai saat meninggalnya almarhum. Kemudian Pasal 14 Staatsblud 1917 No. 129 menjelaskan bahwa, adopsi berakibat putusnya hubungan hukum antara anak yang diadopsi dengan orang tuanya sendiri, kecuali:

1. Mengenai larangan kawin yang berdasar atas suatu tali kekeluargaan.

2. Mengenai peraturan hukum pidana yang berdasar pada tali kekeluargaan.

3. Mengenai ganti rugi biaya-biaya perkara dan sandera.

4. Mengenai pembuktian dengan seorang saksi.

5. Mengenai bertindak sebagai saksi.

Ditinjau dari hukum adat, pengangkatan anak tidak selalu mengakibatkan terputusnya hubungan perdata dengan orang tua kandung. Meskipun pada umumnya dengan terjadinya pengangkatan anak, orang tua angkat akan menggantikan kedudukan orang tua kandung. Sehingga tanggung jawab orang tua kandung akan beralih kepada orang tua angkat (Arif Gosida; 1985)

Pada dasarnya akibat hukum yang timbul dari pengangkatan anak itu tidak terlepas hubungannya dengan tata cara pengangkatan anak yang telah dilakukan. Hal ini sesuai dengan yang dinyatakan oleh B. Bastian Tafal bahwa: Pengangkatan anak yang dilakukan tanpa disertai dengan upacara-upacara khusus dan tanpa suratsurat, maka pengangkatan anak seperti ini tidak memutus pertalian keluarga antara anak yang diangkat dengan orang tua kandungnya.

Meskipun secara lahiriah hubungan anak itu terputus dengan orang tua kandungnya karena dimasukan ke dalam keluarga orang yang mengangkatnya, tetapi secara batiniah hubungan antara anak dengan orang tua kandungnya tetap ada. Kemudian dengan saudara angkat timbul hubungan seperti layaknya saudara kandung dan dengan keluarga atau kerabat dari orang tua angkatnya dianggap sebagai sanak keluarganya sendiri. Selanjutnya dalam upacara perkawinan bagi anak angkat perempuan, maka yang menjadi wali nikahnya adalah orang tua kandungnya atau saudara laki-laki sekandung dari anak angkat tersebut (Bastian Tafal; 1989). Dalam hal hubungan dengan orang tua kandungya tidak terputus, maka hak dan kewajiban anak angkat masih bercabang dua yaitu terhadap orang tua angkat maupun terhadap orang tua kandung. Hal ini mempunyai konsekuensi lebih lanjut bahwa anak angkat yang tidak terputus hubungannya dengan orang tua kandung akan menerima warisan baik dari orang tua kandung maupun dari orang tua angkat.

Keadaan seperti ini biasanya terjadi pada masyarakat parental. Akan tetapi sesuai dengan keanekaragaman sistem hukum pengangkatan anak di 
berbagai daerah di Indonesia, maka pandangan masyarakat dalam hubungannya dengan kedudukan anak angkatpun beraneka ragam pula. Kadang anak angkat mendapat warisan dari orang tua angkat berupa harta asal dan harta bersama, tetapi terkadang hanya harta bersama saja. Sedangkan pengangkatan anak menurut Hukum Islam pada dasarnya diperbolehkan tapi semata-mata hanya didasarkan pada tujuan untuk membantu anak-anak terlantar dan hal itu tidak membawa akibat hukum apapun. Hal ini disebabkan karena dalam hukum Islam ada larangan pengangkatan anak dalam pengertian adopsi yaitu pemberian status kepada anak sama dengan status anak kandung. Pengangkatan anak menurut Agama Islam tidak membawa akibat hukum dalam hak hubungan darah, perwalian dan pewarisan dengan orang tua kandungnya. Anak angkat tetap memakai nama orang tua kandungnya dan tetap menjadi ahli waris dari orang tua kandungnya (Budiarto: 1991)

\section{Pengertian Hak Warisan}

Pengertian hukum kewarisan menurut Pasal 171 huruf a Kompilasi Hukum Islam adalah hukum yang mengatur tentang pemindahan hak pemilikan harta peninggalan (tirkah) pewaris, menentukan siapa-siapa yang berhak menjadi ahli waris dan berapa bagiannya masing-masing. Dalam konteks yang lebih umum, warisan dapat diartikan sebagai perpindahan hak kebendaan dari orang yang meninggal dunia kepada ahli warisnya yang masih hidup. Mewaris berarti menggantikan tempat dari seseorang yang meninggal dalam hubungan hukum harta kekayannya. Hubungan-hubungan hukum yang lain, misalnya hubungan hukum dalam hukum keluarga (Soetojo Prawirohamidjojo; 2001)

Dalam redaksi yang lain, Hasby AshShiddieqy mengemukakan, hukum kewarisan adalah hukum yang mengatur siapa-siapa orang yang mewarisi dan tidak mewarisi, bagian penerimaan setiap ahli waris dan cara-cara pembagiannya. Berbeda dengan dua definisi di atas, Wirjono Prodjodikoro menjelaskan, warisan adalah soal apa dan bagaimana berbagai hak-hak dan kewajiban-kewajiban tentang kekayaan seseorang pada waktu ia meninggal akan beralih kepada orang lain yang masih hidup. Waris dalam bahasa Indonesia disebut pusaka, yaitu harta benda dan hak yang ditinggalkan oleh orang yang mati untuk dibagikan kepada yang berhak menerimanya. Pembagian itu lazim disebut Faraidh, artinya menurut syara' ialah pembagian pusaka bagi yang berhak menerimanya. Menurut Syamsul Rijal Hamid bahwa pengertian warisan adalah berpindahnya hak dan kewajiban atas segala sesuatu baik harta maupun tanggungan dari orang yang telah meninggal dunia kepada keluarganya yang masih hidup (Syamsul Rijal: 2011). Warisan itu menyalurkan pikiran dan perhatian orang ke arah suatu kejadian penting dalam suatu masyarakat tertentu, yaitu ada seorang anggota dari masyarakat itu meninggal dunia. Untuk itu, melihat hukum kewarisan Islam diperlukan wawasan kesejarahan, paling tidak sistem sosial dan sistem hukum yang melingkupi ketika Islam itu diturunkan.

Pasal 171 huruf h KompilasiHukum Islam menyebutkan bahwa "anak angkat adalah anak yang dalam hal pemeliharaan untuk hidupnya sehari-hari, biaya pendidikan dan sebagainya beralih tanggung jawabnya dari orang tua asal kepada orang tua angkatnya berdasarkan putusan pengadilan". Keterangan diatas menjelaskan bahwa adopsi atau pengangkatan anak tidak mendapatkan tempat apalagi pengertian dalam hukum islam. Sebagaimana Islam mengharapkan 
ayah mengingkari nasib anaknya tanpa alasan yang benar, ia juga mengharamkan anak menisabkan dirinya kepada yang bukan nasabnya, atau dipanggil nama yang bukan nasabnya, atau dipanggil dengan nama yang dinisbatkan kepada selain ibunya sendiri.

Menurut hukum Islam pengangkatan anak hanya dapat dibenarkan apabila memenuhi ketentuan-ketentuan sebagai berikut:

1. Tidak memutuskan hubungan darah antara anak yang diangkat dengan orang tua biologis dan keluarga.

2. Anak angkat tidak berkedudukan sebagai pewaris dari orang tua angkat, melainkan tetap sebagai pewaris dari orang tua kandungnya, demikian juga orang tua angkat tidak berkedudukan sebagai pewaris dari anak angkatnya.

3. Anak angkat tidak boleh mempergunakan nama orang tua angkatnya secara langsung kecuali sekedar sebagai tanda pengenal / alamat.

4. Orang tua angkat tidak dapat bertindak sebagai wali dalam perkawinan terhadap anak angkatnya.

Kedudukan anak angkat menurut Kompilasi Hukum Islam adalah tetap sebagai anak yang sah berdasarkan putusan pengadilan dengan tidak memutuskan hubungan nasab / darah dengan orang tua kandungnya, dikarenakan prinsip pengangkatan anak menurut Kompilasi Hukum Islam adalah merupakan manifestasi keimanan yang membawa misi kemanusiaan yang terwujud dalam bentuk memelihara orang lain sebagai anak dan bersifat pengasuhan anak dengan memelihara dalam pertumbuhan dan perkembangannya dengan mencukupi segala kebutuhannya.
Pembagian harta warisan bagi anak angkat menurut Kompilasi Hukum Islam adalah dengan jalan melalui hibah atau dengan jalan wasiat wajibah dengan syarat tidak boleh melebihi $1 / 3$ (sepertiga) dari harta warisan orang tua angkatnya, hal ini untuk melindungi para ahli waris lainnya.

\section{Bibliografi}

ABD-FIK, Ensiklopedia Hukum Islam, Jakarta: PT. Ichtiar Baru Van Hieve, 1997.

Asad M Al Kalali, Kamus Indonesia Arab, Jakarta: Bulan Bintang, 1987.

Atunas Sudijono, Pengantar Statistik Pendidikan, Cet. III. Jakarta: CV. Rajawali, 2001.

B. Bastian Tafal, Pengangkatan Anak Menurut Hukum Adat Serta Akibat-akibat Hukumnya di Kemudian Hari, Bandung: Cita Pustaka, 2001.

Departemen Agama RI, Al-Qur'an dan Terjemahannya, Bandung: Diponegoro, 2005.

Djaja S. Meliala, Pengangkatan Anak (Adopsi) di Indonesia, Bandung: Sinar Lentera, 1982.

Eman Suparman, "Hukum Waris Indonesia dalam Perspektif Islam, Adat dan BW"' (Bandung: PT Rafika Aditama, 2011.

Hazairin, Hendak Kemana Hukum Islam, cet 3, Jakarta: Tintamas, 1976.

Hermawan Wasito, Pengantar Metodologi Penelitian, Cet. I, Jakarta: PT Gramedia, 2002.

Hilman Hadikusuma, "Hukum Perkawinan Indonesia menurut perundangundangan Adat dan Agama", Bandung: Mandar Maju, 2007.

Imam Abi Abdillah Muhammad bin Ismail, Shohih Bukhari, Juz II Beirut, Libanon: Daar Al Kutub Al Ilmiyyah. 
Indonesia Legal Center Publising, Undang-undang RI no. 3 th. 1997 tentang, Pendidikan Anak, Jakarta: PT Abadi, 2004.

M. Abdurrahman, KHI di Indonesia, Jakarta: Akademika Presindo, 1995.

M. Budiarto, Pengangkatan Anak Ditinjau Dari Segi Hukum, Jakarta: Gafindo, 1991.

Mahmud Syaltut, Al Fatawa, Kairo Mesir: Dar al Qalam, 1999.

Masri Singarimbun dan Sofian Effendi, eds., Metode Penelitian Survai, Jakarta: Cet. VIII LP3ES, 2007.

Shanty Dellyana, Wanita dan Anak di Mata Hukum, Yogyakarta: Kurnia Kalam Semesta, 2000.
Soedaryo Saimin, Perundanganundangan dalam Pengangaktan Anak, Jakarta: Bulan Bintang, 1993.

Suharsimi Arikunto, Penelitian Tindakan Kelas, Jakarta: Bumi Aksara, 2008, Cet. VI.

Undang-undang RI NO. 03 Tahun 1997, Tentang Peradilan Anak, 2004.

Zakariya Ahmad Al Bary, Hukum Anak-anak dalam Islam, Jakarta: Bulan Bintang, 2000.

Zakiyah Darajat, Ilmu Fiqh, Jilid III, Yogyakarta: Dana Bhakti Wakaf, 1995.

\section{Copyright holder:}

Suaib lubis, Khairani (2020).

First publication right:

Action Research Literate

This article is licensed under: 